\title{
Image, Function, Meaning, and Structure: The Role of Aphorisms in the Kazakh Epic Poem Kyz Zhibek
}

\section{ב Muhammadgali Abduov, Nazilya Abduova, Nicolae Stanciu}

In this article, the function of aphorisms in folk song, which also contains lyrical and dramatic elements, is analysed and defined through cultural (mostly folklore) literature, and linguistic methods. The main purpose of this paper is to show the role of the gnomic words generated by folk creators in an epic poem's plot, their main functions in the development of conflict and the aesthetic expression of the work. Therefore, the meaning of symbols has been interpreted in close connection with the actions, archetypes and metaphors inserted in the structure of the song. Using as an example the song "Kyz Zhybek", which is a prominent creation in Kazakh folklore, and reviewing research papers on the subject, the present article follows the contrastive analysis in researching the echoes of archetypal traditions in a Muslim cultural frame. Ethnos in culture remains in an attempt to recover the identity of a group using what seems specific in folklore, history, and linguistics and to track them in an original ideology articulated on national and universal bases.

This paper may help researchers when studying folklore heritage, with understanding the scope of using the aphorisms and the main function actualised by them in folk literature. In addition, the role of aphorisms in a folk song is systematised, and their historical and identity significance is underlined.

KEYWORDS: Aphorisms, Kazakh folk song, archetypes in folklore and localisation of the motifs, expressive means, romantic characteristics

\section{INTRODUCTION: KAZAKH FOLKLORE BETWEEN UNIVERSAL AND NATIONAL}

Resulting from the assimilation of archetypal motifs in national folk literature developed under the auspices of romanticism, the Kazakh songs called zhyr have acquired great importance in the attempt to define the specificities of and framing the ethnicity of modern Kazakhstanis. However, the academic approaches to the subject of Kazakh folklore and the attempt to interpret its creations in the wide frame of universal mythology and following their significance to identity have remained minimal. Except for some local or Russian researchers, there are only a few international scientists who have developed an 
interest in the hermeneutical exercise of decoding symbols in the texts of Kazakh folk poems, and the number of publications in the English language remains quite limited (Aasland 2018, 1-14).

The main creations generated by ordinary people contain traditions imbued with folk spirit and, due to the general characteristics of the folklore (syncretic, traditional and oral), they have continuously changed their variants. They have sometimes passed into authors' literature as different layers of intertextuality (Bakhtin 1981, Plett 1991, Robbins 1996, Allen 2000) and a sublime expression of originality and wisdom. In addition, the texts in folklore are the "reflection of social construction and ideology" (Bourdieu 2002, 137) ensuing in creative activities performed by different folk artists who actualise the variants. The artists perform a discursive action in a group or in a specific situation in a syncretic context (dancing, fighting, singing, and uttering lyrics) while being watched by the members of the cultural community, which may be a group, a tribe or a nation. Some categories of texts, such as folk songs, imply an "active imagination" (Jung 1958, 48), visualisation and a guided fantasy involving a world in which heroes, marriage-eligible maids, parents, or relatives interrelate with their tools. They could also imply tutelary power words as guiding spirits for forecasting fates by seeking wisdom for the community through forms that provide access to other spaces.

Seen as spiritual manifestations, all folklore creativity in different national tradition is "a mirror of culture" (Dundes 2007,55 ), specifically a modality to framing realities and expressing them in words. Some complementary and multilevel perspectives were considered in this hermeneutical exercise: from the linguistic point of view, the analysis should discover archetypal motifs, patterns and structures, performance styles, and compare narratives existing within and across cultures (Wierzbicka 1997, 36); for the psychological tradition, the text comprises cognitive schemas, content analysis, and semantic networks generated in a cognitive frame or "scene" (Crapanzano 1981, 126, 2006, 381); for an ethnic, linguistic and metaphorical tradition, it is important to discover links between "ethnos and language" (Tolstoi 1995, 33).

All folk creations belong to an archetypal stock of love stories common to different cultures as the myth of marriage as a foundation and revealing a "diffuse and multilingual mythology" (Bahtin 1975, 163) while being outlined not only by some simple concepts but also by using special eloquent samples of masterful and metaphoric language. It is the case of the content of deep thoughts framed by figures of speech that give a special flavour to Kazakh folk poems, which equally combine epic, dramatic, and lyric elements intertwined in archetypal stories with some specific nomadic, and pastoral touches merged in perfect harmony. More specifically, such a language has a definite impact within the entire plot, starting from the exposition to the rising conflict and its completion as a tragic love story. As an artefact of folklore, the text is "woven, thus it can stand as ready metaphor for any human construction and $[. .$.$] as the final product of folk performance"$ (Toelken 1996, 12; 20) displaying a syncretism of gesture performance and verbal singing.

Focusing on the famous lyric-epic song, Kyz Zhybek, and aiming at identifying the parallels between the archetypal motifs in folklore this article points out the role of aphorisms as gnomic language by underlining the "theoretical significance of comparative 
studies" (Anikeeva, 2010, 73, Khunagova 2007, 206). Therefore, the primary approach to the subject is, on the one hand, archetypal and cultural, mostly tracking sources of the motifs used in the folk song as belonging to universal mythology, and, on the other hand, comparative and national, while discovering and interpreting the reverberations of such motifs in Kazakh folklore as an original and perhaps involuntary attempt to define ethnic specificity. By adapting linguistic, literary, and mythological techniques to the folklore settings, the analysis and comparison contribute to the hermeneutical exercise of decoding and interpreting symbols.

\section{BACKGROUND: FOLK EPIC - CONTENT, STRUCTURE AND SIGNIFICANCE}

Kyz Zhibek is a masterpiece of Kazakh folklore, which adapted archetypal themes like love and marriage, heroism and the myth of foundation to a specific national and religious context, mainly based on nomadic traditions and containing broader Islamic culture motifs. The love story recreated the pattern of Romeo and Juliet by transposing a tale into an imaginative space quite similar to the Kazakh one and by embroidering images and words in a well-balanced dosage of traditional genres. This story is projected into mythical space and time resonating some pre-state nomadic organisation and tradition of tribes that have existed in pre-medieval times in Central Asia, as belonging to Turkic ethnicity ${ }^{1}$. Developing at a slow pace and reflecting the main parts of a typical epic conflict, the song begins with recreating the atmosphere in the family at the time of falling in love. The initial sets of the story describe in detail the appearance and the character features of the prototypical couple, the lad Tolegen, the son of a tribe's chieftain, whose family lives in a remote eastern land of what is now Kazakhstan and his female correspondent, Kyz Zhibek, a maid of similar social condition, owning large fields in the steppes of the central part of the country. As an irrational happening, love drives the partners to fight to surpass all traditional requirements of belonging to noble nomadic families: the couple has to pass all steps of pre-nuptial rituals, such as receiving parents' blessing, buying the bride, performing dances with horses, fighting the evil embodied by other suitors and generally persuading the masters to unify their tribes in nomadic communities. The spiritual conflict settled among the main characters of the epos is mostly one between a query for unity embodied by the protagonist, the prince Tolegen, who wants to bring together the main tribes into a great nation after marrying beautiful Kyz Zhibek, and those individuals and warlike people, like his father and his opponent Bekezhan, who prefer keeping the ancient ways and divided tribal power. Kyz Zhibek attracted and enticed Tolegen not only by her beauty but also by her wealth visible in the richly adorned saddle of the camel, covered by furs and in the jewellery made of gold and pearl belt, beads, and earrings.

\footnotetext{
1 For Turkish as different from Old Turkic as ethnicity including mainly history, nomadic cultures, tribal state organiSation, and languages which have emerged and develop in confluent areas, in Central Asia, see Budagov 1997; Clauson 1962, 1972; Dybo 2007; Golden 1991, 1992, 2006, 2011, 2014; Klyashtornyi 2008, Johanson and Csató 1999; Menges 1994; Sevrotjan 1974 onward; Vásári 2004, Zuev 2002.
} 
When a distinguished chieftainship family of a tribe decided to betroth their daughter to a man as a wife, they celebrated for some days, so the groom's horsemen were ready to follow all the procedures and waited to take the bride home as soon as the celebration was over and the newlyweds had received the blessing of both families.

Like other numerous local names, that of the debutant girl - Kyz Zhibek - expresses the soft, almost immaterial condition and at the same time conveying a brilliant, noble and mysterious situation and an unpredictable fate (literally, the name means "girl of silk"). In contrast, the name of the lad - Tolegen - suggests the masculine heroic potentialities of the protagonist. The eligible maiden has almost the same attributes common to other traditions: she is a nubile young girl, appealing and seducing the mortals with her beauty, ready for marriage and richly adorned for this purpose. As a matter of specificity, she is a Muslim maid willing to follow all the rules of traditional wooing and marriage and, besides the horse rides and sharing the gifts with her best friends, she practices Islamic and nomadic traditions like washing her hands and thanking Allah for a meal by moving the palms over the face or treating the young girls and fellows with fermented mare milk.

Tolegen mounted his horse and departed to his homeland to ask for his father's blessing to marry Kyz Zhibek, which at the social level equals accepting the unification of the tribes. While coming back to take her from her parents' house, after being blessed by his father, the protagonist is murdered by Bekezhan, the other contender to Kyz Zhibek's hand in the most unjust way: he seems to let him go to his beloved, but in fact, he sends an arrow to the hero, which put him down for death. This uncompleted pre-nuptial ritual, which resembles a myth of foundation through a possible marriage, ends, leaving the tribal social organisation at the previous stage. The heroine gives birth to a son and will be protected by Tolegen's brother, who married her.

Archaeology, history, and folk literature throw light on some aspects of the comparable life habits of ethnic communities found at the confluence of civilisations but, at the same time, leave numerous dark corners, which favoured the flourishing of mythology. Echoes of Indo-European and Turkic heroism, initiation rituals, kinship systems, nomadic and pastoral traditions and horse cult reverberate in this poem and prove the original aspects of the myth of love, foundation and pre-state formations as tribes (Kz. zhusy) ruled by chieftains who own vast herds, such as thousands of horses, master the groups of people and are proud of their specificity. As the Kazakh poet Abay Kunabayev pointed out in his Book of Wisdom, "the worst enemy of a Kazakh person is another Kazakh person" (Kunanbayev 2009, 303) and "the force of a nation consists of its unity" (id.:142).

The classical genres of literature are frequently found in the song: epic, lyric, and dramatic. What appertains to the epic can be identified in the conflict evolution, characters, space and time, actions, and sets. For setting the initial scene and providing background information about the space and the time, history recovers the classical pattern of tales and generate a "narrative with a multiplicity of representations of the past" (Bloch 1998, 101) via suggested ambiguity through indefinite dimensions of space and time while mentioning the main characters imagined as a couple involved in a pre-marital ritual. Developed through the actions of some main characters who are accompanied by tribes' members and representatives, the conflict evolves from a quiet atmosphere to tremendous events and a 
tragic end. Although the title suggests a love story with a beautiful maid as a protagonist, it is quite difficult to dissociate and determine what the prevalent topic of the poem is: the cult of ancestors as preservers of traditions, the tragic story of an unaccomplished love, or the heroic background in which battles among the tribes (Kz. zhuzy) amplify the conflict.

Unlike the classical myth of tragic and possibly unaccomplished love in the poem, a significant difference can be noted: although they belong to opposite tribes, the characters have comparable social status: she is a princess of unique beauty, intelligence, and dedication; he is a knight and the son of a very rich noble (Kz. bazarbay) and a hero (Kz. batyr "hero") ${ }^{2}$. In some folk traditions, the hero's virtues might be the synthesis of the great features of nomadic identity and become personages of old stories of battles coming down to this time and being preserved in collective memory in some main types: the founder, the ruler, and the eligible lad. They are paramount leaders and men of physical endurance and strength allied to moral qualities, such as boldness and propensity for plunging into dangerous adventures like archery, hunting, conquering new places, and settling down as well as demonstrations of wisdom.

As a marriageable lad, both a herder and a warrior, the hero demonstrates his powers in the functional context created by his future wife; among some pretenders, he is the chosen one sought by divinity as seeking to win his bride and unify the divided tribes made of people dominated by envy from different parts of the country. He leads armies and drives big groups of horses into ritualistic round dances, travels long distances between his home and tribe to the furthest lands where his future wife lives. Both families have their own rules of castes, their tribal organisation and the traditions of the marriage become an attempt of accommodating opposite ideas and establishing a bigger state organisation ruled by a wise chief.

The woman has a functional role in the hero's life of providing the context for him to demonstrate his winning qualities of seeking to conquer his bride and form a family and a dynasty. The main female character, Kyz Zhibek, plays the most important role in choosing the hero of her story: in an archery ritual executed with covered eyes, she first moves in a circle with two arrows, selects one and sends it to a place meant to be the centre of her new world. Winning a bride displays a "heroic vision on marriage common to ancient Turkic traditions in all its forms such as wooing, capture, negotiation" (West 2007, 247). Kyz Zhibek is a nomadic princess riding horses across the endless steppe and generously sharing gifts with her female friends, who will become her bride maids in the marital rituals. Therefore, her future husband does not rescue her after passing some "spiritual quests" (Eliade 1984: 34) meant to accomplish perfection and to prove his heroism but followings more a traditional modality of asking for a blessing from both families and especially by the fathers. Although abduction is a motif found in ancient and medieval Armenian and Caucasian cultures (Colarusso 2002, 150) and still performed in present-day Kazakhstan, the pre-nuptial ritual follows the rules of asking for hand and soul, wooing the bride and receiving the permission from the parents of the maid.

\footnotetext{
2 For the ranks among Kazakh nobles, their description and role in the tribal society, see Kunanbayev 2009: 298-299.
} 
At the same time, the marriage becomes a myth of unifying some tribes into "nomadic confederations" (Cheng 2018, 124) and founding a new order of the world, first because some pretenders sought the hand of the beautiful maiden who defeats numerous suitors before finding her match and, second, because through marriage together with the new noble family, a dynasty of khans will be born. In summary, as in other traditions, the heroic, marital and foundation motifs are intertwined in a tapestry combining archetypal dimensions and specific ones like nomadic, pastoral, and Islamic. The suitors are numerous, and this makes the bride so desirable that the men of distinction fight for her hand.

The betrothal is simpler than in other traditions consisting of choosing the most beautiful girl from some groups who ride caravans of camels, giving/offering and taking, a visit of the bachelor's friends to the maiden's parents, who are endowed to permit the girl to marry the prince. Sharing the gifts imply in the poem a "contractual exchange", (Mauss 1966, 15) visible in some moments of the narrative: first, as a steppe duchess riding a horse as the female protagonist shares her jewellery with the other maidens in the tribe in a supreme gesture of generosity; second, accepting the gifts becomes the main step of accepting the proposal of a knight coming from remote areas and riding a white horse; third, the hospitality of nomadic people is revealed in sharing fermented mare's milk with all female and male members of the community while presenting the future bride with furs, jewellery and colourful clothing. In the old Turkic ritual of "buying the bride"'(Mustafina 2001, 30), among some significant presents offered to the damsel by her future sister-in-law are a richly adorned cape whose name implies the sun (Kz. saukele is a compounded word from sau "sunny", "beautiful" and kele "head" is a part of Kazakh female celebration and wedding attire) and is worth one hundred horses, rich cattle or even a khan's yurt. Alongside this decorative piece of female attire, some motifs belonging to agricultural and nomadic traditions bring specific aspects to the general ritual of gift exchange in the process of engagement: while entering the maid's shelter, the future couple is blessed by the girl's mother who throws over the newly formed couple seeds as a gesture supposed to induce fertility into the new pair. Meantime, outside of the nomadic shelter and pre-nuptial place, the best maids offer furs of different animals for inducing richness in cattle of the newly formed couple and showing their nomadic dowry. A piece of precious fur goes around the margins of the cape being the first circle of decorations and distinction on the bottom of this conic shape.

A widespread motif of Turkic traditions (Dzhumagulov 1960, 72) can be noticed in the pre-nuptial ceremony: the couple sleeps together for one or several nights with a chastity golden belt and a sword placed between partners. As female and male symbols put together on the bed, clothes, the magic objects, are purified after being passed over a fire function at the same time, as signs of separation and unification. The girl's mother veils them with delicate silk clothes and formulates the interdiction of having sexual intercourse prior to the coronation marked by the wedding ceremony. However, even though they have not yet received the groom's father's acceptance for marrying Kyz Zhibek, the maid shares her pearls and undoes her tresses in a gesture of accepting the proposal and promising to be devoted to her future husband. Both gestures of spreading the pearls around and unplaiting the tresses mark the ritual of separation from her family 
and to some extend the symbolical loss of virginity and the passage to the new condition of a married woman.

The universal motif of a horse together with chariot symbolism common to ancient traditions at birth, wedding and funeral "widely spread about 3600-3400 BC in today Kazakhstan" (Anthony 2007, 203, Walker 2015, 35), resonates in different facets in Kazakh folklore, either as a sign of distinction, delicacy or noblesse and richness appropriate to the high condition of the bride princess or groom knight. It also resonates in symbolic dances performed by horse riders during the pre-marital rituals and as a sacrifice. Recently, an embracing couple buried together with a horse, jewellery and items such as cauldrons belonging to the Bronze Age excavated in Karaganda region (Stewart 2018) prove the ancient practices of chariots, chivalry and horse riding in different parts of the country. Wild stallions are tamed by skilled lads and dance near the wall of the nomadic fortress, where the princess works and prepares clothes for the future husband. Mounting the horse of the future husband represents another significant moment in accepting the proposal and an act of spousal nature, a significant stage in the rite of separation and the last step of leaving their own space followed by the beginning of a new life under the husband's roof.

Interestingly, as the real wedding has not yet happened, all these images are projected in the groom's imagination and exposed in melodic words as reflections of thoughts while moving from his house to his wife's shelter. Finally, the horse given as a gift to Tolegen as a messenger of fate goes to the hero's father asking to be blessed. It has all the attributes of a mythological animal with white skin, was born in a witch's hut, bred with embers and has waited for his master to tame him.

As for dramatisation in both discourse and actions, not only is the dialogue relevant but so too are the tragic situations of the protagonists: between the initial plans and reality, numerous changes occur in the structure of the plot generating a conflict between the forces of good and evil. Although the girl is prepared to marry the prince and has accepted his proposal, her actions while waiting for the chosen lover to come back from his parents' house reflect other specific and nomadic motifs, such as guarding the cattle, raking hay for horses or even visiting the blue mosque in the middle of the steppe to ask for divine support.

Analysing individual works of living folk traditions, we often pay attention to the ideas and images, plot development, variety of genres, but also to various artistic means. Nevertheless, it would be appropriate to note that the poem specifically belongs to the universal heritage of folklore, and it is expressed by allegorical means, mainly aphorisms and proverbs. Just a few attempts have been made so far for integrating the Kazakh folklore into an extended frame of interpretation as universal myths and for following the role of proverbs in defining identity. However, whatever work of folklore is taken into consideration, the special function of this correlation of image/motifs to myth denotes a long process of assimilation and representation through which the life of people has been filtered through a sieve of national consciousness and tradition and finally established in the language.

In Kazakh folklore, one of the distinct species found at the genre interference is the category of lyric-epic and dramatic poems called "zhyr(s)". Their common specific 
feature is also manifested in thematic consonance; for example, it is not an exaggeration to say that all nations of the world have heroic and ethical poems built on love themes. "In general, the theme of love is archetypal and traditional for the folklore of all nations and all times. It is also widely and fruitfully developed in the pearls of the Kazakh lyric-eposes Kozy-Korpesh - Bayan Sulu and Kyz-Zhibek' (Azibayeva, 1998, 119). It can be said that among the Kazakh folk songs, these two works stand out for their wide distribution among the people, their constant use of performers, the significance of the plot and the imagery of the language. In the process of the vocal performance of these works, attention is drawn to their motifs that are disclosed separately from other poems. Since these ethical creations are performed orally, their rhythm and tune are different. This characteristic speaks of another specific feature of the lyric-epic poems.

The hero wins his fame in combat, and it is closely associated with deeds of battle, foundation, and love. As a fame seeker, he knowingly and willingly takes risks at the cost of his life: Tolegen is required to ask for permission to marry Kyz Zhibek and to ask his father to lay aside vanity and accept the unification of their tribes into a bigger state formation. After duelling with his competitors to recover his honour in the right battle, the protagonist should encounter his opponent's father and die on the way back to his lover. Through his death, the hero transcends his mortality and is assimilated, together with fighting men to the category of founders and rulers, who are honoured by the community in their songs and recognised to be as wise as their ancestors, who have defended the same ideals of unity. Like in other traditions, the hero lays his high fame of glorious deeds and makes a name for himself, thus infusing the community being with the grandeur of sacred personages of a society of warriors.

Wherever the origin of aphorisms can be found, they were formed on a folk basis at a certain time as an expression of traditional wisdom. There are also certain reasons for this. "Actually, aphoristic genres in their diverse varieties - sentences, maxims, reflections or thoughts, paradoxes were formed in the era of classicism with its normative poetics with strictly genre regulation and close attention to the stylistic form" (Zhirmunski, 1987, 6).

In folk works of art, numerous images have been passed down from generation to generation through oral channels, and many artistic and moral values have been accumulated. In the process of using these values, various cultural traditions of neighbouring countries were assimilated and used at a certain level.

In starting the analysis of aphorisms used in folklore sources, it is impossible to circumvent the problem of the text, because the inseparable relationship between the words in folklore and the content of the text is obvious (Dianova 2010, 51). In science, in general, there are enough opinions about the historical, linguistic, meaningful and semantic features of aphorisms ${ }^{3}$.

Nalichnikova 2016, 122, Bagapov, Gasheva 2016, 60 


\section{DISCUSSION: IMAGE, FUNCTIONS AND MEANING CONVEYED BY APHORISMS}

As simple time narratives of multiple representations denoting the past and the way an ethnic group thinks, the poems do not contain details on heroic deeds of courage and boldness, as in classical epos, but the essence of the work is devoted to the love of a great knight, Tolegen, for a beautiful girl, Kyz Zhibek, transformed by folk imagination into a prototypical mythical couple. Suitably so, the historicity of the characters "does not long resist the corrosive action of mythisation" (Eliade 1959, 42)

The beginning of the event is shaped in twists and turns with structures characteristic of folk traditions for legends and associated with the search for the groom (Kz. jigit) by the bride (Kz. kalyndyk). These "aphoristic words" (Korotkih 2016, 114) often used in folk poems are found in this work at the very beginning. For example, the first hero's action draws the audience's attention when Tolegen went to choose a bride without the permission of his parents. His mother hurries him, and she reaches her goals by an instructive combination of sounds and words. In these lines, the expression "to the righteous" means gifting the noble or the sinless with a horse, and the bad or the sinner with the ram, which are often found in our folklore traditions as symbols of a high condition or a poor one. Two main conflicts are suggested at the beginning of the poem: first, the protagonist does not obey parents' advice and does not ask for permission to start his search for the bride; second, two opposite conditions are set at the beginning of the adventure: the rich and the poor. The main specificity of this combination lies in the fact that in antiquity, after the death of a person who was considered to be a righteous one during his life, he deserved the respect of all people. As a result, they sacrificed cattle with the wish that he would be their patron, supporting their wishes like a totem that protects the soul of the man during his afterlife.

It is no exaggeration to note that this tradition has retained its basic specificity to this day and continues like the testament of the fathers, the words left by ancestors to subsequent generations and it is mainly based on the knowledge and education of humanity. Seen as a knowledge transfer, the ancestors' words give life-competence to the followers in the form of concepts or thoughts associated with words (Albekov, Alpysbayeva, Auyesbayeva 2017,33). The presence of gnomic words in the texture of the song improves the expressiveness of a work of art, and it is believed that while they are being uttered, they have a magic impact on a person. They actualise a function similar to that performed by traditional artistic means in folklore (Yuldybaeva, Mingazova, Kayumova 2017, 667). As allegorical expressions, the aphorisms contain, together with comparisons, metaphors, and symbols, some rhythmical instruments meant to bring musicality to the poem. Used in a single consonance sound, repetitions improve the beauty and the attractiveness of words as in the wish expressed by Tolegen's mother:

"Mother has come sobbing, /The father is sitting, suffering, /Many enemies that are jealous / Will be ready to come back."

(Kz. Anan keldi zarlanyp, / aken otyr sandalip, / kore almagan kop dushpan, / syrtynan keler qamdanyp.) 
Contributing to the exposition of the poem, the space and indefinite time of the plot, together with the parents' subtle feeling of anticipation, forecast the initial and possible tragic dimensions of the conflict evolution: the quiet shivering atmosphere suggests a storm that is coming. The verbal epithets for father and mother contrasting the motion and sitting, related by the same mournful anticipation are correlated to the unknown and imprecise number of virtual enemies guilty of a sin: jealousy. The combination of "Kore Almagan Kop Dushpannan" (many enemies that are jealous) appear on the basis of deeply meaningful words in the proverb "Dushpany kore almaidy, agaynyn bolip bere almaidy" (The enemies are envious; the relatives cannot share his bitterness). The meaning of this expression may be that if one suddenly becomes the owner of some kind of good, then the enemies, of course, will look with envy, and if one's encounter any difficulties, then one's family will not be willing to help. As in other folk traditions, the verbalisation of concepts originates in the life experience.

The events of the epic are exposed in a strict form similar to one of the "beads in a thread". Even metaphorical expressions are arranged in a specific order and repeated as the events' representation in a logical succession of actions in the plot. As an expression of archaic society, the creation of a cosmologic model implies at least three elements: the emergence of a hero acting as a creator of a new world; the occurrence of the opposite forces that explain the conflict evolution and the act of foundation based on a spiritual search and sacrifice (Eliade 1959, viii). When some details of the mythical events (Osmushina, Ingle, 2016, 417) are introduced, they are also not included in the replay process. This feature of the epic works was underlined by a Russian scientist: "The laws of the epos do not allow two heroes to act simultaneously in different places" (Propp 1975, 93) and the use of repetitions of individual words occurs at the end of the verse lines. As a result of this, even the ancient patriarchal environment, people who have seen a lot in their day utter their words in a certain rhythm in the form of sayings, and this becomes a traditional phenomenon.

For example, Tolegen's mother, in a conversation with her son, points out the beauty of a prototypical hero whose features are very natural, suggesting the main dimensions of a nomadic leader, who must be beautiful, brave, and rich. In Kazakh traditions, these are pre-conditions of becoming a ruler, namely being a bay or a batyr "boyar, governor":

"The beauty of your land will be in a tale about willow, /The beauty of the river will be in the precipice, /The beauty of a horseman will be in cattle richness. /If you have rich cattle of deer/Then you will become a khan."

(Olkenin korki tal bolar, / ozennin korki zhar bolar, / zhigittin korki mal bolar, / malyn bolsa, karagym, / karah basyn khan bolar.)

The landscape is made of some significant motifs that reverberate with the universal symbolism of willow as a bridge between this world and the afterlife (Mencej 1996, 31 35, Colarruso and Sabiev 2016, 72-73) and suggest the highest rank of Kazakh nomadic knights. Retaining similar meanings in different traditional cultures, the willow symbolises "the power of life and rapid growth, vitality and regeneration" (Tolstoi 1995, 333). In the Kazakh epic, it occurs in a story about the beauty of a land destined to be conquered and mastered by the young knight. The hero meant to become a knight, and a khan should 
pass all the quests of initiation. In this nomadic world of cattle breeders, the horseman's profile develops as a master of the field and a future leader of people.

The image is articulated by suggestive motifs of naturalness which denote the rich symbolism of primordial elements (air, earth, water) and project the shape of the knight into the cosmic landscape having the tree as a protective centre of his world. The folk collective imagination created in minimal details a cosmological model projected in the mirror of the water and, in an indirect story comprising the bank of the river, the richness of the hero and the shiver of the willow. At the discursive and lyrical levels, the word for the future implying a condition, bolar, is repeated at the end of the first three lines and at the end of the strophe itself, augmenting the idea of crucial events expected to happen and improving the suggestion of inner rhythmical movement. This phonetical, semantic, syntactic, and prosodic pattern of underlining the rhetoric of the poem was recovered in later individual poems denoting the "value of folklore for the classical literature of Kazakh authors" (Aktulum 2017, 34).

The method of plot development, namely the way of organising events, noted in the content of the epic works, in the traditions of the Kazakh folk poems is associated with the philosophy of Dzungars or Kalmyks tribes whose members wanted to convey through the history of love a myth of heroism and foundation (Artykbayev 1997, 87). The meaning of this method can be said to convey to the listeners, to their consciousness, the idea that the events described in the stories are taken from life as it seems obvious in the epic Kyz Zhybek. One of the matchmakers is Kalmyk khan Koren. At first glance, it may seem that this is a particularly worthy plot. However, we can note that the creator of this epic does not deviate from the main tradition. As a Russian scholar elegantly put it, "the emergence of the epos as in the form of public consciousness is associated with the specificity of the historical situation and the internal laws of the development of society" (Volkova, 1984: 8). The quests the hero should pass for obtaining the maid's hand are meant to prove his heroism and to reveal his intelligence, all features of a knight who is preparing to become a husband and a ruler. Therefore, the pretender at the princess' hand is more resourceful, attractive, and smarter than his opponent, Koren, although they are almost in the same position of chiefs of the tribes. The hero should fight the monster, in this case, the competitor in the bride search, and instruct the brother, who may become his successor at the throne and have to acquire the right skills of heroism and wisdom. The roles in the court hierarchy are metaphorically exposed by the khan's assistant, Karshyga, who is the elder friend and the best man of the main hero:

"You are my young bush on the river bank, /My winged horse, which has escaped forward. /The white horde of horses was where you went, /You have lived an interesting life so far. /Why are you sad?"

(Kolge bitken quragym,/ suyrylyp ozan pyragym, / aq orda boldy kyrgyenin, / qyzyq dauren surgenin, / nege qapa bolasyn?)

Tolegen's portrait, as presented by his close friend, reveals the status of a chosen knight, who is appreciated by his fellows and deserves the love of the most wanted princess in the land. Built in a gradation, the image of the prince is attractive and natural: 
the hero is compared with young shoots of reed thickets growing in beautiful places and a winged horse, which overtakes hundreds of other horses. These comparisons have been known since ancient times and are related to the type of acting image. At its core, a winged horse is a special type of steed often found in legends and myths that came to Kazakh folklore either from the east or the west. In the Islamic faith, the winged horse refers to the type of steeds living in paradise. Its peculiarity, unlike other horses, is that, compared with other horses, he is strong, slim, speaks like a man and has wings for flying. It is an individual in the form of a horse. At its core, this is understandable to an attentive person. The artistry of national epic works and the language features of their use were influenced by famous heroic epics.

The conflict is developed in simple lines with minimal actions and sets projected in imaginative possible stories and suggestive characters ready to experience a spiritual journey and to accomplish the triple condition of a founder, a husband, and a ruler. In Kazakh poetry, the eligible maidens have almost the same attributes as in Indo-European traditions expressed in the sun glow goddess features: they are nubile young women, who appeal and seduce mortals, are ready for marriage, and adorn themselves excessively. Strong maids live the indoor life dispensing wisdom and choosing their partners as a modality to build a family and a dynasty and to escape from the place they are secluded. The colours of their garments and hair are also significant as their attire is made of silk, their hair is golden, and their jewellery demonstrates their status: a necklace with diamonds and a silver crown. Mounting the horse of the future husband represents the acceptance of the proposal in the gradual process of leaving her place to follow the man with whom she will start a new life.

In the epic Kyz Zhibek, there are significant places where aphorisms are used regularly, often in a grouped form supporting images, giving the correct discursive expression and assuring the inner musicality of the poem. Such cases suggest the long-term use of these metaphors and symbols believed to be also associated with a person's mood. More specifically, they are used almost automatically when a person is very happy or, in contrast, very upset. For example, at the moment when Bekezhan comes to Kyz Zhebek and informs her about Tolegen's death, Kyz Zhebek's complex answer can be said to be completely built in the style of aphoristic words:

"Damned Bekezhan! /Don't show up to me /Finished your job. /How could you decide /To raise hand on /A such person? /May God give you back /What you did to me, /Damned rogue! /God damn you /Who spawned me. /Let your wife and children cry. / When will you feel bad /Let no one come to you."

(Ata nalet, Bekezhan! / Korsetpe magan tusindi, / bitiripsin isindi, / qaytyp kozin qudi eken, / sol sekildi musindi, / aldyna қudai keltirsin, / magan an qylgan isindi. / Atana lagynet, qaraqshy! / Qudayim seni qargasyn, / toniri meni zharatsa, / qatyn, balan zarlasyn, / basyna qyin is tusse, / qasyna eshkim barmasyn.)

In the last six lines of this passage, built in the form of curses, the construction of the song performed in the second instance of a failed marriage is based on the model of aphorisms found in consonance with each other. It should also be noted that themes such as the problem of revenge are often found in epic works. More precisely, a blood feud 
is more often used in the heroic epic, and it is found in other forms quite related to the symbolism of brothers and expressed by the fight for revenge among certain heroes. In the epic Kyz Zhybek, the heroine's six brothers take revenge for Tolegen's death. They will kill Bekezhan, restoring through blood and sword her favourite suitor's honour. The frequency of this motif widely used in the epics is stated in the works of researchers of Kazakh folklore (Dyadyun 2017, 59) where the wedding has become a tragic saga of courtesy and redemption, with the bride in the central role.

The aphorisms and metaphorical words occur not only in the plot but also in the imagination of heroes who conspicuously address their ideal bride in dreams or discourse. As a master of the house, the bride is imagined as stepping out into her courtyard to draw water from the lake, where she at once recognises her groom riding a horse and discovers the good features of people whom he will rule.

As a myth of foundation, the ideal marriage has become a good modality of acquiring wisdom for founding a kingdom. The wisdom of the future ruler is shown in his comprehensive vision of people and the world while returning from acquiring the bride. Significantly, in this discourse about the qualities of a land master, the protagonist indirectly prepares his brother as a successor while forecasting a tragic future and initiating him for the new condition of being a possible ruler. The hero's discourse projects the career of his brother and imaginatively transfers his responsibilities in the case of unexpected and unfortunate encounters and underlines the power of the words as representations of the thoughts. A coherent poetical expression of water symbolism reverberates in subtle echoes of mirroring, reflection and a spiritual journey of the protagonist meant to become a ruler of the land after surpassing all the obstacles and becoming the wisest in the realm:

"Getting close to the best, /You recognise the virtues of people. /Located in a beautiful land. /You will recognise the merits of the lake. /So, you will know the virtues of the word, /Deep in thought, /It affects the soul of man."

(Zhaqsylarmen zhanasyp, / el qadirin bilgeysin, /suly zherdi qonys qyp, / kol qadirin bilgeysin, /terennen kesip tolgaytyn, /kenildin kozin qozgaytyn, / soz qadyryn bilgeisin.)

The main topic of the poem is love between two young people, but the story is projected in a wider field of heroism and traditions, which transform the aspiration to an ideal romance in a tragic story of death before achieving true the dream of love. A prototypical love story was adapted to a nomadic context, and an original expression of romance and heroism can be found not only in folk creation but also in other forms of art, such as the film version of the poem, also called Kyz Zhibek. A good sense of friendship and fairness is conveyed alongside Tolegen's wishes addressed to his brother and successor Sansyzbay. Amplifying the feeling of uncertainty, the second part of the elder brother's advice for his possible successor points out the importance of communication with the people in the realm and the amplitude of the self:

"Having put effort into any business, /You will be friends with your equal self. /Listen to these words of mine /My successor Sansyzbay, /Getting close to the best, /You will recognise the virtues of people."

(Talap qylyp ar iske, teninmen oynap-kulgeysin, bul sozimdi tyndagyn, zhetkinshegim, Sansyzbay, zhaqsylarmen zhanasyp, zhurt qadirin bilgeysiң.) 
The aphoristic value of each line is obvious as expressed by the combination of advice settled in the present simple and imperative forms and the future tense as a way of marking the potentialities of a leader able to discover the virtues of his community. Having set off to his beloved, Tolegen could not reach his main goal of taking her to his parents' house because he died in the hands of Bekezhan, his opponent, for the hand of a beautiful girl. There is such an interesting detail in the epic: before closing his eyes forever, Tolegen saw six geese flying in the sky and talked to them to convey greetings to his native land and to his relatives. According to the idea adopted in the epic, the geese have a mandate to deliver Tolegen's word. It seems that this episode is used on the basis of the concept adopted by the people, who, connecting geese with swans, consider them sacred, holy. In contrast, this episode correlates with surprising phenomena, more precisely, with features of magical use. In epic works, the use of magical phenomena is a common circumstance (Dzhumaeva 2018, 194).

Another situation in which the aphoristic words are used is the image that combines the metaphors with exaggeration by referring to the comparative method as a persuasive tool of oratory. Nevertheless, this method has found application at a certain level and in the works of Kazak national folk poets called akyns or zhyrau embodying two types of creators, namely keen on detail and nuanced respectively on the general description of the plot. Tolegen's mother reveals an entire scene of food symbolism in relation to her personality and the role of meat, bread, butter and honey in the Kazakh culinary folk tradition:

"I said rump, but she gave under-fat (tidbit), /I said sugar, she gave honey, /Gave bread, smearing it with butter. /Gave a variety of food. Raised, holding on the palms, / Forgive, if he was capricious."

(Zhaya dese zhal bergen,/sheker dese bal bergen,/ mayga salyp nan bergen, /ar aluan as bergen, /alaqandap osirgen, / yerkelik_kylsam keshirgen.)

These are Tolegen's thoughts about his mother. In the understanding of the Kazakhs, the opinion that under-fat is more expensive than the rump, honey is more expensive than sugar, butter is more expensive than bread turned into instructive words, and in a certain rhythm, excellent adhesion is transmitted in the form of an order to descendants. The cuisine of Kazakhs reflects a rich specificity and symbolism either by the presence of horse meat in their dietary or through comparative expressions on different sorts of meat and sweets.

Pre-state organisation and envy among the tribes reflect a stage of evolution in the life of Kazakh society, and it is expressed in the hierarchy of the groups. As in Turkish tradition, in which the sultan has some advisers and deputies who participate in the army and judgement, in Kazakh tradition the khan has some hierarchically organised nobles called $b i$ "respected, wise person". When one of the prominent three biis of the Kazakhs, Kazybek bii, went with the ambassadors to the Dzungarian khan in his childhood, critical people praised Kazybek, saying that although he was a child, it was clear that he would become the leader. The spouse of the khan who considered Kazybek a child said to him: "The one whom you consider to be a hair cutter, as if turned out to be a fighting horse, the one whom you consider to be a crow, no matter how it turned out to be a falcon". It directly corresponds to another popular expression: "There is no falcon with an intact 
wing; there is no horse with a whole hoof'. These aphorisms are used without change in the epic Kyz Zhibek, underlining the importance of hunting with falcons for the tradition of nobility and the specificity as a sign of identity still actualised in the identity of the nation.

"No falcon with intact wing, /No horse with a whole hoof. /An order came from Allah - /No reimbursement of a life lived."

(Kanaty butin sunkar jok, / Tulagy butin tulpar jok. /Alladan ukim kelgen son, / Oteshek omir sury jok.)

As birds of freedom flying through the air, eagles have been recovered as markers of Kazakh ethnicity in modern times, and they are represented on the nation's flag together with agricultural and mineral resources suggestions of wealth projected in a blue-sky background. Together with the horses as a symbol of ancestry and heroism, these birds make complete the image of aspirations and ethnic specificity called "Kazakhness as a civilisational endeavour" (Mkrtchyan 2014, 16).

This folk poem of Kazakh folklore preserves interwoven motifs and myths of neighbouring traditions like love and marriage, taming horses and making them dance, hunting with horses and eagles, taking the bride to the husband's house, the journey to an ideal love tragically ended by the protagonist's murder, water and willow as symbols of self-reflection and wisdom, all harmonised in an original story which has acquired some religious touches of Islamic traditions.

Almost all motifs encountered in the folk epic Kyz Zhibek belong to a "common inheritance" (Watkins 1995, 414) of interfering civilisations and displaying local details mostly generated by the assimilation of universal traditions into a nomadic and pastoral society - an ethnic group that adapted them to the religious standards of Islam. As mythological topics, they were analysed in this paper from a comparative point of view combining some main perspectives: folklore, linguistics, and overall ethnic dimensions for tracking the similarities of such legendary material which confirm a specific symbolism.

\section{CONCLUSIONS}

The folklore of Kazakhstanis as members of Turkic ethnicity and Muslim religion has transformed artistic forms of elements of ancient mythological concepts and images. The folklore tradition organises the world with the help of original forms and situations, while the everyday social reality has become a source and an instrument for making sense of the life phenomena revealing their genesis and role in defining ethnicity and specificity.

Filtering archetypal traditions through the sieve of religion and assimilating myths in an original reverberation have been suggestive modalities of building up a national ideology of identity, in which the sacral geography, the ancient history, the folklore, the language and Islam represent the main axes.

In folk traditions, the maid's beauty and the hero's virtue and wisdom might be celebrated for generations or centuries as usually such characters have lost their identity and become legendary and prototypical personages. The folk imagination projected a historical couple and its extended family into an exemplary heroic and tragic love story 
transforming a marital event into a new scene relevant for humanity and more specifically for Kazakh spirituality. Through bravery and love motifs united in an original myth of foundation, the lyric-epic poems offer models of heroism and morality considered to be definitory for Kazakh ethnicity. The beautiful maids and the horsemen attempt to surpass their condition and to climb to the heavens in an allegory of integration into the cosmos. Conquering a new land, winning a bride and attempting to settle a new order in a realm by unifying the tribes into a bigger pre-state formation equals an ascension into heaven and his image will be preserved in the collective memory.

The use of aphorisms in the epic Kyz Zhibek as well as in other folk songs in Kazakh folklore is quite common, and the function they perform is diverse, spanning from configuring realities to giving expressivity and musicality to this genre. The aphorisms have a special impact on enriching the artistic characteristics of folk songs, on helping with the quick perception in the national identity of the events described here. The metaphors contained in aphoristic expression bring a specific rhythm of utterance, contributing to the beauty of the singing and, thus, the positive impression of the listening audience. Overall, the aphorisms contribute to the understanding of traditional poetical methods of working with allegorical words.

\section{REFERENCES}

Aasland, E. 2018. "Contrasting Two Kazakh Proverbial Calls to Action: Using Discourse

Ecology to Understand Proverb Meaning-making." In Proverbium: Yearbook International Proverb Scholarship, vol. 35: 1-14.

Abdiraiymkyzy, M. 1998: Islam alemi. "World of Islam,” 1998, Almaty: Kazbaspa-KT: 10-13.

Akilova, K. 2011. "Sovremennoe iskusstvoznanie v aspekte mejkulturnogo dialoga." (Modern art studies in the aspect of intercultural dialogue.) Almati: Credos.

Aktulum, K. 2017. "Yazinsal folklore". (Literary folklore), Milli Folklor, (116): 33-46. https:// www.researchgate.net/publication/321824291_YAZINSAL_FOLKLOR, (accessed January 15,2019$)$.

Albekov, T. K., Alpysbayeva, K. B., Auyesbayeva, P. T. 2017. "Distinctive and educational

features of Kazakh folklore by the example of 'Words of Ancestors."' In Espacios, 38 (45): 33-34. https://elibrary.ru/item.asp?id=31062040 (accessed November 25, 2018).

Allen, G. 2011. Intertextuality. 2nd edition, London and New York: Routledge.

Anikeeva T. A. 2010: "Literatura i folklor drevnih turkov centralnoi Azii," (Literature and folklore of the ancient Turks of Central Asia.) In New Historical Journal 4(26): 73-82. https:// elibrary.ru/item.asp?id=19547985 (accessed November 25, 2018).

Anthony, D. W. 2007. "The Horse, the Wheel and Language." How Bronze-Age Riders from the Steppes Shaped the Modern World. Princeton and Oxford: Princeton University Press.

Artykbayev, Zh. O 1997. "Istorija Kazahstana.” The History of Kaazakhstan. Karaganda: Arko.

Azibaeva, B. U. 1998. "Kazahskii dastannii epos.” Kazakh Dastan epic. Almaty: Gylim.

Bahtin, M. 1975. "Voprosy literatury i estetiki." Problems of literature and aesthetics. Moskva: Nauka. 
Bakhtin, M. 1981. The Dialogic Imagination. Edited by M. Holquist. Trans. C. Emerson and M. Holquist. Austin: University of Texas Press.

Bloch, M. E. F. ed.) 1998. "Time narratives and the multiplicity of representatives of the past.” In How We Think They Think. Boulder, C. O.: Westview Press.

Bourdieu, P. 2002. The Logic of Practice, translated by Richard Nice. Standford: Standford University Press.

Cheng, C. 2018. Rethinking Prehistoric Central Asia: shepherds, farmers and nomads. Abingdon and New York: Routledge.

Colarusso, J. 2002. Narts'Sagas. Ancient Myths and Legends of Circassians and Abkhazians. Assembled, translated and annotated by John Colarusso. With a new introduction by Adrienne Mayor. Princeton and Oxford: Princeton University Press.

Collarusso, J and Sabiev, T. ed.: 2016. Tales of Narts. Ancient Myths and Legends of the Ossetians. translated by Walter May. Princeton: Princeton University Press.

Crapanzano, V. 1981. “Text, Transference and Indexicality.” in Ethos, 9(2): 122-148.

Crapanzano, V. 2006. “The Scene: Shadowing the Real.” In Anthropological Theory, 6(4): 378-405.

Dianova T. B. 2010. “Kontekstualnie edinici v sostave pesenno_liricheskih tekstov_tipologiya I Funkcii" (Contextual units in the composition of song and lyrical texts: typology and Functions). In Folklor: Text i Context, Moskva: Gosudarstvennii Respublikanskii Centr Russkogo Folklora: 50-67.

Djumaeva N. D. 2018. “The peculiarities of magical objects in English folklore.” In Molodoj uchonyi, (9): 194-196.

Dundes, A. 2007. “The Meaning of Folklore. The Analytical Essays of Alan Dundes.” Edited and introduced by Simon J. Bromner, Logan. Utah: Utah State University Press.

Dyadyun S. D. 2017. "The image of an orphan in the folk world picture of the Khanty people." In Vestnik Urgovedenia (Bulletin of Ugric Studies), vol. 1 (28): 58-64.

Dybo, A. B. 2007: Lingvisticheskije kontakty rannyh fond tjurkov. Leksicheskii fond. Pratjurskii period, Moskva: Nauka.

Dzhumagulov, A. 1960. "Sem'ja i brak u kirgizov Čjujskoj doliny, Frunze," (Family and wedding at Kirgiz from The Valley Čjujska). Frunze (Bishkek).

Eliade, M. 1959. “Cosmos and History: The Myth of eternal Return.” Translated from French by Willard R. Trask. New York: Harper and Brothers Publishers.

Eliade, M. 1969. “The Quest. History and Meaning in Religion.” Chicago: Chicago University Press. Midway Reprint.

Golden, P. B. 1991. 'Turkic Nomads' in Archivum Eurasiae Medii Aevi, vol. 7, Wiesbaden: Otto Harrassovitz: 41-86.

Golden, P. B. 1992. An Introduction to the Turkic World. Ethnogenesis and State Formation in Medieval and Early Modern Eurasia and Middle East, Wiesbaden: Otto Harrassovitz.

Golden, P. B. 1998: 'The Turkic People: A Historical Sketch' in The Turkic Languages, Edited by Lars Johanson and Evá A. Csató.

Golden, P. B. 2006. 'Some Thoughts on the Origins of the Turks and Shaping of the Turkic People' in V. H. Mair (ed.) Contact and Exchange in the Ancient World, Honolulu: Hawaii University Press: 136-157.

Golden, P. B. 2011. Central Asia in World History, Oxford and New York: Oxford University Press.

Golden, P. B. 2014. 'Qipčag' in Turcology and Linguistics. Eva Agnes Csató Festschrift. Edited by Nurettin Demir, Birsel Karakoç, Astrid Menz, Istanbul: Hacceteppe Üniversitesi. 
Johanson, L. \& É. Á. Csató (eds) 1998: The Turkic Languages, London and New York: Routledge.

Jung, C. G. 1958.“The Undiscovered Self(Present and Future).” London and New York: Routledge and Kegan Paul.

Kazakh epos. 1958. "A Collection of Texts, Almaty: Kazahskoj Gosuderstvennoi Literatury"

Klyashtornyi, S. 2008 : Old Turkic Runic Texts and History, Bucharest : Editura Academiei Române and Brăila: Editura Istros.

Korotkih T. A. 2016. “O stilisticheskom ispolzovanii krylatyh vyrazhenii. ” (On The StylisticUse of Winged Expressions, 114-120 №1(105) Izvestiya Volgogradskogo gosudarstvennogo pedagogicheskogo universiteta.

Kozybaev, M. K. and Azhigali, Z.E. (eds.) 2001: “Obychai i obrjady Kazakhov v proshlom i nastajaschchem," (Kazakhstanis' Customs and Rites in the Past and Present.) Almaty: Gylim.

Kunanabayev, A. 2009: Black Words. The Book of Wisdom, Almaty: Mezhdunanrondyi Klub Abaya.

Mauss, M. 1966. "The Gift. Forms and Functions of Exchange in Archaic Society” Translated by Ian Cunnison. Introduction by E.E. Evans-Pritchard, London: Cohen and West Ltd.

Mencej, M. 1996. "Vrba posredznik ismeđu ovog i onog sveta” in Kodovi slovenskih kultura, 1: 31-36.

Menges, K. H. 1994: The Turkic Languages and People. An Introduction to Turkic Studies, $2^{\text {nd }}$ revised edition, Wiesbaden: Harrassowitz Verlag.

Mkrtchyan, N. 2014. "The Notion of Kazakkness behind the symbolic nation building of Kazakhstan." in Central European University Political Science Journal, Budapest: Central European University Press, 9(1-2): 16-38.

Mustafina, R. 2001. "Bytovoj islam v Kazahstane" (Household Islam in Kazakhstan) in Kozybaev and Azhigali 2001: 28-34.

Nalichnikova I. A. 2016. "Aforizm kak zhanr, maloformatnyj tekst i universal'noe vyskazyvanie" (Aphorism as a genre, a small-format text and a universal utterance.) In Philological Sciences. Questions of theory and practice, 4 (58): 121-123. www.gramota.net/materials/2/2016/4-3/33.html, (accessed November 25, 2018).

Osmushina A. A., Ingle O.P. 2016. " Ethno-pedagogical value of the comical of the mordovian People. ” In Integration of Education, vol. 20 (3): 415-421. http://edumag.mrsu.ru/index. php/en/articles-en/61-16-3/478-10-15507-1991-9468-084-020- 201603-11. (accessed January 15, 2019).

Plett, H. F. (ed.) 1991. Intertextuality. Research in Text Theory 15. Berlin: Walter de Gruyter.

Propp V. Y. 1976. "Fol'klor i dejstvitel'nost," (Folklore and reality). Moskva: Nauka.

Robbins, V. K. 1996. Exploring the Texture of Texts: A Guide to Socio-Rhetorical Interpretation. Harrisburg: Trinity Press International.

Sevortjan, E. V. 1974: Etimologicheskij slovar'tjurskih jazykov, Moskva: Nauka

Stewart, W. 2018. "Skeletons of 5000-year-old Romeo and Juliet lovers found buried alongside remains of two sacrificed horses pulling a chariot into the afterlife." In The Sun, July 27, 2018. http://www.thesun.co.uk/news/6879249/bronze-age-romeo-juliet-couple-buried-kazakhstan-horse-skeletons/. (accessed August 23, 2018).

"The Epic of Gilgamesh," 1998. A New Translation with an Introduction by Andrew George. London: Penguin Classic.

Tolstoi, N. I. ed. 1995. "Slavjanskje drevnosti. Etnolingvisticheskii slovarj, vol. 1-4, Moskva: Mezhdunarodnoe otnoshenija.

Tursynov E. D. 2001: “Drevnetyurskij fol'klor: Istoki i stanovlenie,” (Ancient Turkic folklore: Origins and formation: 170.) Almaty: Daik-Press. 
Vásári, I. 2005: Cumans and Tatars. Oriental Military in the Pre-Ottoman Balkans, 1185-1365, Cambridge: Cambridge University Press.

Volkova Z. N. 1984. "Epos Francii: Istoriya i yazyk francuzskih ehpicheskih skazanij,” (Epos of France: History and language of French epic tales.) Moskva: Nauka.

Walker, H. J. 2015. "The Twin Horse Gods. The Dioskouroi in Mythologies of Ancient World." London and New York: Tauris.

Watkins, C. 1995. "How to Kill a Dragon. Aspects of Indo-European Poetics." New York and Oxford: Oxford University Press.

West, M. L. 2007. “Indo-European Poetry and Myth.” Oxford: Oxford University Press.

Wierzbicka, A. 1997. "Understanding the Cultures Through Their Key Words. English, Russian, Polish, German, and Japanese.” London and Oxford: Oxford University Press.

Yuldybaeva G. V., Mingazova L. I., Kayumova G. F. 2017. "The folk epic tulyak and susylu, zayatulyak and hyuhylu: the history of record and the plot." In Astra Salvensis," vol. 52: 673-679. https://elibrary.ru/item.asp?id=31262449. (accessed November 25, 2018).

Zhirmunski, V. M. 1987. "Razmishleniya i aforizmi francuzskih moralistov XVI_XVIII vekov," (Thoughts and aphorisms of the French moralists of the XVI-XVIII centuries.) Leningrad: Hudojestvennaya literature.

Zuev, Ju. A. 2002. Rannie tjurki očerki istorii i ideologii. Almaty: Dajk-Press.

\section{IMMAGINE, FUNZIONE, SIGNIFICATO E STRUTTURA IL RUOLO DEGLI AFORISMI NELLA CANZONE POPOLARE KAZAKA "KYZ ZHIBEK" \\ Muhammadgali Abduov, Nazilya Abduova, Nicolae Stanciu \\ $\infty$}

In questo articolo, la funzione degli aforismi nella canzone popolare, che contiene anche elementi lirici e drammatici, viene analizzata e definita attraverso i metodi culturali, principalmente folcloristici, letterari e linguistici.

Lo scopo principale di questo articolo è evidenziare e mostrare il ruolo delle parole gnomiche generate dai creatori popolari nella trama immaginaria, le loro principali funzioni nello sviluppo del conflitto e l'espressione estetica dell'opera.

Pertanto, il significato dei simboli è stato interpretato in stretta connessione con le azioni, con gli archetipi e con le metafore inserite nella struttura della canzone. Usando come esempio, la canzone "Kyz Zhybek", che è una creazione di spicco nel folclore kazako, e rivedendo gli articoli scientifici sull'argomento, l'articolo segue l'analisi contrastante nella ricerca delle tracce delle tradizioni archetipiche in una cornice culturale musulmana.

L'ethnos nella cultura rimane nel tentativo di recuperare l'identità di un gruppo usando ciò che sembra specifico nel folclore, nella storia e nella linguistica e seguendone un'ideologia originale articolata su basi nazionali ed universali. 
Questo documento può aiutare i ricercatori, quando studiano l'eredità del folclore, a comprendere la portata dell'uso degli aforismi e della funzione principale da essi realizzata nella letteratura popolare. Inoltre, il ruolo degli aforismi in una canzone popolare è sistematizzato e il loro significato storico e d'identità viene rimarcato.

Muhammadgali Abduov, Ph.D., Professor, Dean of the Faculty of Philology, E. A. Buketov Karaganda State University, Mukanov street 1, 100028 Karaganda, Kazakhstan; abduov_m@mail.ru

Nazilya Abduova, Ph.D., Assistant Professor, Deparment of Kazakh Language and Literature, Faculty of Philology, E. A. Buketov Karaganda State University, Mukanov street 1, 100028 - Karaganda, Kazakhstan; nazilya_abduova@mail.ru

Nicolae Stanciu, Ph.D., Visiting Professor, E. A. Buketov Karaganda State University, Mukanov street 1, 100028 - Karaganda, Kazakhstan; Institute of Romanian Language, Bucharest; nickstanciu@gmail.com 